\title{
Vegetation history of central Chukotka deduced from permafrost paleoenvironmental records of the El'gygytgyn Impact Crater
}

\author{
A. A. Andreev ${ }^{1}$, E. Morozova ${ }^{2}$, G. Fedorov ${ }^{2}$, L. Schirrmeister ${ }^{3}$, A. A. Bobrov ${ }^{4}$, F. Kienast ${ }^{5}$, and G. Schwamborn ${ }^{3}$ \\ ${ }^{1}$ Institute of Geology and Mineralogy, University of Cologne, Zülpicher Str. 49a, 50674, Cologne, Germany \\ ${ }^{2}$ Arctic and Antarctic Research Institute, Bering St. 38, 199397 St. Petersburg, Russia \\ ${ }^{3}$ Alfred Wegener Institute for Polar and Marine Research, Department of Periglacial Research, Telegrafenberg A43, \\ 14473 Potsdam, Germany \\ ${ }^{4}$ Faculty of Soil Science, Moscow State University, Vorobievy Gory, 119899 Moscow, Russia \\ ${ }^{5}$ Senckenberg, Research Institute and Natural History Museum, Research Station for Quaternary Paleontology, \\ Am Jakobskirchhof 4, 99423 Weimar, Germany \\ Correspondence to: A. A. Andreev (aandreev@uni-koeln.de)
}

Received: 5 March 2012 - Published in Clim. Past Discuss.: 20 April 2012

Revised: 18 July 2012 - Accepted: 23 July 2012 - Published: 17 August 2012

\begin{abstract}
Frozen sediments from three cores bored in the permafrost surrounding the El'gygytgyn Impact Crater Lake have been studied for pollen, non-pollen palynomorphs, plant macrofossils and rhizopods. The palynological study of these cores contributes to a higher resolution of time intervals presented in a poor temporal resolution in the lacustrine sediments; namely the Allerød and succeeding periods. Moreover, the permafrost records better reflect local environmental changes, allowing a more reliable reconstruction of the local paleoenvironments. The new data confirm that shrub tundra with dwarf birch, shrub alder and willow dominated the lake surroundings during the Allerød warming. Younger Dryas pollen assemblages reflect abrupt changes to grasssedge-herb dominated environments reflecting significantly drier and cooler climate. Low shrub tundra with dwarf birch and willow dominate the lake vicinity at the onset of the Holocene. The find of larch seeds indicate its local presence around $11000 \mathrm{cal} \mathrm{yr} \mathrm{BP}$ and, thus a northward shift of treeline by about $100 \mathrm{~km}$ during the early Holocene thermal optimum. Forest tundra with larch and shrub alder stands grew in the area during the early Holocene. After ca. $3500 \mathrm{cal}$ yr BP similar-to-modern plant communities became common in the lake vicinity.
\end{abstract}

\section{Introduction}

El'gygytgyn Impact Crater is located in central Chukotka, approximately $100 \mathrm{~km}$ north of the Arctic Circle (Fig. 1). The crater was formed 3.6 Myr ago (Gurov and Gurova, 1979; Layer, 2000). As inferred from geomorphologic research, the study area was never glaciated after the time of the impact ca. 3.6 Myr ago (e.g. Brigham-Grette et al., 2007 and references therein), and thus, the lake is probably the longest archive for Arctic terrestrial environmental and climate history. El'gygytgyn Late Quaternary lacustrine palynological records were first reported by Shilo et al. (2001), followed by more continuous and detailed records published by Lozhkin et al. (2007) and Matrosova (2009). The studied sediments comprise the oldest continuous Quaternary pollen record in the Arctic, which provides history of vegetation and climate changes since ca. $350 \mathrm{kyr}$.

Generally, sediments from large and deep lakes are valuable paleoenvironmental archives which contain pollen data reflecting vegetation and climate history of surrounding areas. However, such pollen records reflect predominately regional environmental changes because of the large input of long distance wind-transported pollen into the spectra. The Lake El'gygytgyn sediments, where the pollen from a several thousand square-kilometer source area is trapped, also provide a reliable record of extra-regional vegetation and climate changes (Lozhkin et al., 2007; Matrosova, 2009). The 


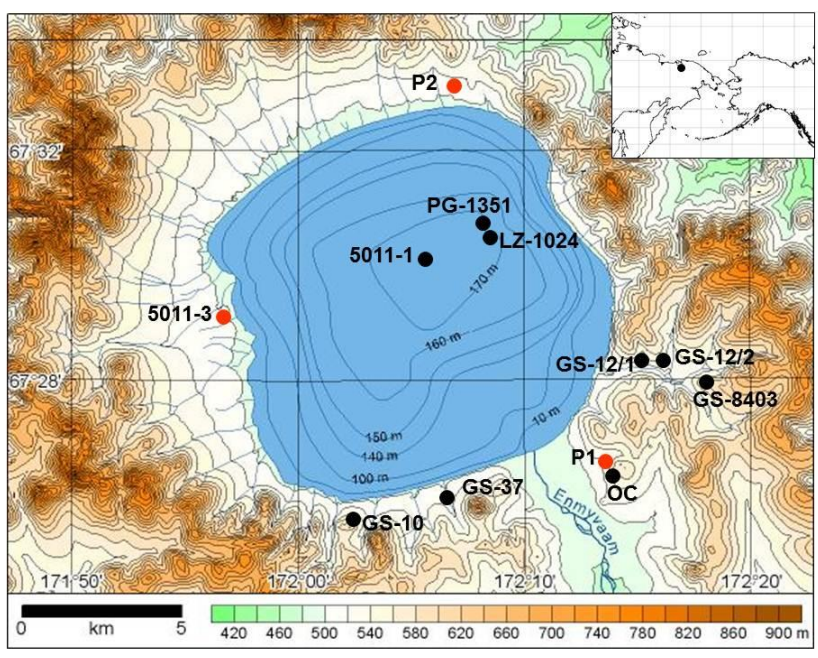

Fig. 1. Location map of the study sites and mentioned cores and sections. OC - Olga Creek terrace section from Enmyvaam River valley (Glushkova and Smirnov, 2007; Shilo et al., 2008; Glushkova et al., 2009).

importance of such continuous long-term regional records is obvious. Nevertheless, short-term palynological records reflecting local paleoenvironmental dynamics are also highly desired. These records document predominate changes in local vegetation and may be compared with extra-regional variations in order to better understand the role of local and regional vegetation in the paleobotanical records, resulting in more reliable environmental reconstructions. Moreover, these records often have better temporal resolution for some abrupt changes such as Younger Dryas, providing unique possibilities for high-resolution environmental studies.

Palynological studies of surface samples from the study area complement reliable reconstructions. A total of 56 surface sediment samples from Lake El'gygytgyn and 26 surface soil samples from the crater slopes have been recently studied (Matrosova et al., 2004; Matrosova, 2006, 2009; Glushkova et al., 2009). These studies demonstrate that pollen of trees and shrubs may reach up to $82 \%$ of the recent lacustrine spectra although the only willow and dwarf birch stands grow in the crater in protected locations. Although soil pollen spectra reliably reflect the local vegetation, pollen of long-distance-transported taxa dominate even there (Matrosova, 2006; Glushkova et al., 2009). It is characteristic that pollen contents of Pinus pumila and Alnus fruticosa, species not growing in the crater vicinity, may reach up to 15 and $37 \%$ of the spectra consequently. Thus, by interpretations of fossil pollen assemblages it has to be taken into consideration that a significant part of the pollen may have originated from some dozens and even hundreds of kilometers away.

This paper presents palaeoenvironmental and palaeoclimatic changes during the Lateglacial and Holocene inferred from permafrost pollen, plant macrofossil, and rhizopod records from the permafrost surrounding of the El'gygytgyn Crater Lake. The Lateglacial/Holocene transition is considered as a unique period of intensive glaciation and deglaciation events accompanied by remarkable changes in global temperature, atmospheric circulation, air humidity, precipitation and vegetation (Johnsen et al., 1995; Stuiver et al., 1995; Blunier and Brook, 2001). Our studies of three permafrost cores add to a better understanding of paleoenvironmental changes during these time intervals which are not well represented in a high temporal resolution in the lacustrine archive. A comparison of the palynological data from the new permafrost cores and previously studied exposures and lake cores were used to make a local chronostratigraphy scheme because of the partly insufficient geochronological datasets. Such comparison resulted in a more reliable reconstruction of vegetation and climate changes, especially during the transitional intervals from cold to warm periods.

\section{Geographical setting}

The El'gygytgyn Impact Crater is $18 \mathrm{~km}$ in diameter and holds a ca. $170 \mathrm{~m}$ deep lake that has a bowl-shaped morphology ca. $12 \mathrm{~km}$ in diameter (Fig. 1). The crater is superimposed on the Anadyr lowland and was formed in an Upper Cretaceous volcanic plateau (Belyi, 1998). The crater rim comprises peaks between 600 and $930 \mathrm{~m}$ a.s.l. (above sea level), and the lake level is situated at $492 \mathrm{~m}$ a.s.l. Unconsolidated Quaternary permafrost deposits cover the crater bottom surrounding the lake. They show a distinctly asymmetrical distribution with a broad fringe of loose sediment that is 500 to $600 \mathrm{~m}$ wide to the north and west, and only 10 to $20 \mathrm{~m}$ elsewhere around the lake (Fig. 1).

The study area belongs to the continuous permafrost zone with a mean annual ground temperature of $-10^{\circ} \mathrm{C}$ at $12.5 \mathrm{~m}$ depth (Schwamborn et al., 2008a). In 2003, the active layer was about $40 \mathrm{~cm}$ deep in peaty silts and reached 50 to $80 \mathrm{~cm}$ in sand, pebbles, and gravels. The region is characterized by extremely harsh climate with average annual air temperature ca. $-10{ }^{\circ} \mathrm{C}$, mean July temperatures of 4 to $8^{\circ} \mathrm{C}$ and mean January temperatures of -32 to $-36^{\circ} \mathrm{C}$. The precipitation consists of $70 \mathrm{~mm}$ summer rainfall (JuneSeptember) and ca. $110 \mathrm{~mm}$ water equivalent of snowfall (Nolan and Brigham-Grette, 2007). Climate variables are strongly dependent on oceanic influence expressed in decreasing summer temperatures (Kozhevnikov, 1993). According to Kozhevnikov (1993), long-distance atmospheric convection, bringing air masses from the south and north, dominates at the lake area. These air masses bring tree and shrub pollen grains playing an important role in the recent pollen assemblages from long distances. This situation may also have occurred in the past.

The study area belongs to the subzone of southern shrub and typical tundra (Galanin et al., 1997). The modern treeline for larch (Larix cajanderi) and stone pine (Pinus pumila) is 
positioned roughly $100 \mathrm{~km}$ to the south and west of the lake (Galanin et al., 1997 and references therein). Although the northern boundary of shrub alder is reportedly much to the north of the lake, the only shrub alder stands grow approximately $10 \mathrm{~km}$ from the lake, in the Enmyvaam River valley (P. Minyuk, personal communication, 2010). The local vegetation has been well studied during the last decades (e.g. Belikovich, 1988, 1989, 1994; Kozhevnikov, 1993; Belikovich and Galanin, 1994 and references therein).

According to Belikovich (1994), ca. $40 \%$ of the area (low parts of smooth crater slopes and low lake terraces) are covered by hummock tundra with Eriophorum vaginatum, E. callitrix, E. polystachion, Pedicularis pennellii, P. albolabiata, Carex rotundata, C. lugens, Salix fuscescens, S. reticulata, Senecio atropurpureus, Ledum decumbens, Andromeda polifolia, and Vaccinium uliginosum. Ca. $20 \%$ (low-middle parts of crater slopes) are covered by moss-lichens tundra with Cassiope tetragona, Rhododendron parvifolium, Senecio resedifolus, Ermania parryoides, Silene stenophylla, Dryas octopetala, Crepis nana, Potentilla elegans, and Androsace ochotensis. Ca. $15 \%$ (upper mountain plains) are covered by tundra with rare beds with Salix phlebophylla, Pedicularis lanata, Artemisia furcata, Potentilla elegans, Eritrichium aretioides, Minuartia arctica, Potentilla uniflora, Arenaria capillaris, Poa pseudoabbreviata, Cardamine bellidifolia, Saxifraga serpyllifolia, Kobresia myosuroides, and Crepis nana. Ca. $10 \%$ are by nival vegetation with Salix polaris, Cassiope tetragona, Carex tripartita, Phippsia algida, Koenigia islandica, Saxifraga hyperborea, Eritrichium villosum, Primula tschuktschorum, Hierochloe pauciflora. Another ca. $10 \%$ are covered by meadow and shrubby tundra with Artemisia arctica, Aconitum delphinipholium, Arctagrostis arundinacea, Carex podocarpa, Festuca altaica, Luzula multiflora, Senecio tundricola, Thalictrum alpinum, Veratrum oxysepalum. Rare steppe-like communities with Potentilla stipularis, Artemisia kruhseana, Myosotis asiatica, Saxifraga eschscholtzii, Papaver lapponicum, Senecio jacuticus, Woodsia ilvensis, Dianthus repens can be found in rocky habitats. Along the Enmyvaam River and alongside large creeks, grow low willow stands with Salix tschuktschorum, S. saxatilis, Androsace ochotensis, Empetrum subholarcticum, Pleuropogon sabinii, Polemonium boreale, Beckwithia chamissonis, Saussurea tilesii, Lagotis minor, Pedicularis hirsuta and meadowshrub willow communities with Salix alaxensis, S. krylovii, Deschampsia borealis, Chamerion latifolium, Equisetum variegatum, Stellaria fischerana, Potentilla hyparctica, Eutrema edwardsii, Cardamine blaisdellii, Trollius membranostylus, Polemonium acutiflorum, Parnassia kotzebuei and Poa paucispicula.

\section{Methods}

A standard HF technique was used for pollen preparation (Berglund and Ralska-Jasiewiczowa, 1986). A tablet of $L y$ copodium marker spores was added to each sample for calculating total pollen and spore concentrations, following Stockmarr (1971). Water-free glycerol was used for sample storage and preparation of the microscopic slides. Pollen and spores were identified at magnifications of $400 \times$ with the aid of published pollen keys and atlases (Kupriyanova et al., 1972; Kupriyanova and Alyoshina, 1978; Bobrov et al., 1983; Reille, 1992, 1995, 1998). In addition to pollen and spores, a number of non-pollen-palynomorphs, such as fungi spores remains of algae and invertebrate, were also identified when possible and counted. These non-pollen palynomorphs are also valuable indicators of past environments (e.g. van Geel, 2001 and references therein).

At least 250 pollen grains were counted in each sample. The relative frequencies of pollen taxa were calculated from the sum of the terrestrial pollen taxa. Spore percentages are based on the sum of pollen and spores. The relative abundances of reworked taxa (mineralized pollen and spores of Tertiary and early Quaternary age) are based on the sum of pollen and redeposited taxa, the percentages of non-pollen palynomorphs are based on the sum of the pollen and nonpollen palynomorphs, and the percentages of algae are based on the sum of pollen and algae. TGView software (Grimm, 2004) was used for the calculation of percentages and for drawing the diagrams (Figs. 3-5). The diagrams were zoned by a qualitative inspection of significant changes in pollen associations, pollen concentrations and occurrence of particularly indicative taxa. CorelDraw software was used for preparation of the final pollen diagrams.

At a depth of $146.5-151 \mathrm{~cm}$ in core $\mathrm{P} 2$, we detected a number of well-preserved plant remains, picked using a stereomicroscope and identified by comparison with a modern reference material from the Herbarium Senckenbergianum (IQW). Additionally, a Carex identification key (Egorova, 1999) was used.

The core sediments were also studied for testate amoebae tests. The samples were sieved through a $0.5 \mathrm{~mm}$ mesh and testate amoebae tests were concentrated with a centrifuge. A drop of suspension was placed on the slide, and then glycerol was added. Normally, 5 slides were examined at x200-400 magnification with a light microscope.

A total of 33 AMS ${ }^{14} \mathrm{C}$ ages were obtained from the studied deposits (Table 1). Plant macrofossils (i.e. grass remains) were picked from the cores $\mathrm{P} 1$ and $\mathrm{P} 2$ and the uppermost segment of 5011-3 for AMS radiocarbon dating. Because of the lack of plant remains in the lower part of core 5011-3, only bulk organic was dated. AMS datings were done at the Leibniz Laboratory for Radiometric Dating and Stable Isotope Research (Christian Albrechts University, Kiel, Germany) and the Poznan Radiocarbon Laboratory (Adam Mickiewicz 

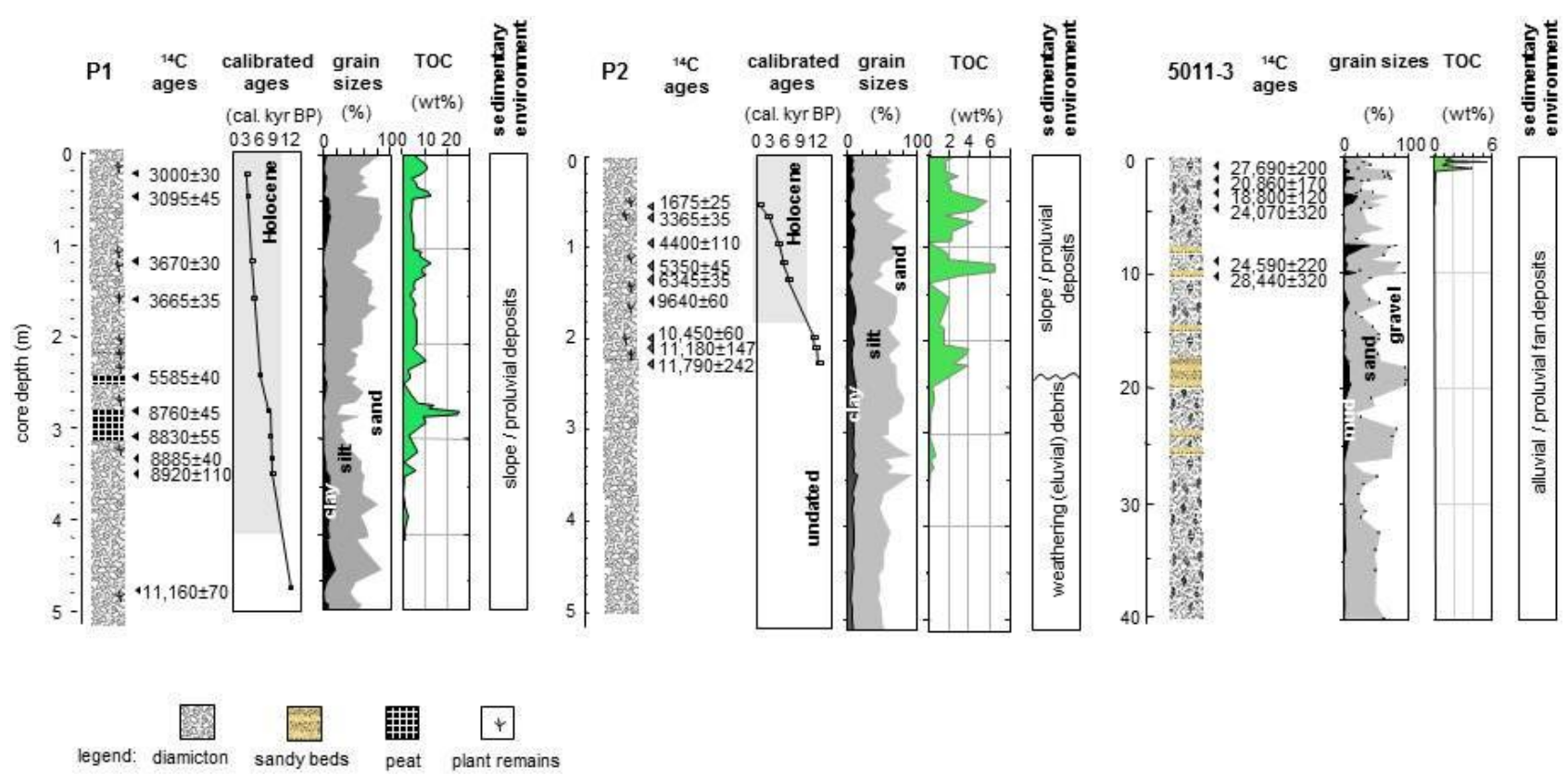

Fig. 2. Lithological, geochronological, grain size and TOC data from P1, P2, and 5011-3 cores.

University, Poznan, Poland). Calibrated ages (cal yr BP) were calculated using “CALIB 6.1.0" (Reimer et al., 2009).

\section{Results}

\subsection{P1 core}

The first permafrost core (P1) was extracted from a piedmont terrace about $1.7 \mathrm{~km}$ southeast of the lake $\left(67^{\circ} 22^{\prime} 26^{\prime \prime} \mathrm{N}\right.$, $172^{\circ} 13^{\prime} 10^{\prime \prime}$ E, Fig. 1) during field work in summer 2003 (for details see Schwamborn et al., 2006). The study site is located on a slope exposed to the southwest with the angle of $5^{\circ}$. The vegetation cover at core site was relatively dense (ca. $80 \%$ ).

The $5 \mathrm{~m}$ slope debris core consists mostly of a silty-tosandy diamicton interpreted as a result from proluvial, colluvial and solifluctional deposition (Schwamborn et al., 2006). Prominent peaty layers interrupt the section between 330 and $220 \mathrm{~cm}$ core depth, which is also reflected in maximum values of total organic carbon (TOC on Fig. 2). Non-identified plant remains from several layers have been dated and show a correct depth-to-age relationship (Table 1, Fig. 2). The oldest date from $463 \mathrm{~cm}$ depth shows that the oldest core sediments are around $13000 \mathrm{cal}$ yr BP old or slightly older.

Generally the P1 sequence is very rich in pollen and palynomorphs (Fig. 3). The studied pollen spectra can be subdivided into 5 pollen zones (PZ). PZ-I (ca. $495-430 \mathrm{~cm}$ ) is dominated by Cyperaceae, Poaceae, and Betula sect. Nanae and Salix pollen. PZ-II (ca. $430-380 \mathrm{~cm}$ ) shows the significant increase of Cyperaceae pollen content, while Betula sect. Nanae content is decreased. PZ-III (ca. $380-330 \mathrm{~cm}$ ) is notable for an increase in Betula sect. Nanae and appearance of small amounts of Alnus fruticosa. Pollen concentration is also increased in the upper part of the zone. The amounts of tree and shrub pollen (predominantly Alnus fruticosa) have a maximum in PZ-IV (ca. 330-265 cm). The pollen concentration is the highest in PZ-V (ca. 265-50 cm), which is notable for high amounts of Betula sect. Nanae, Alnus fruticosa and Cyperaceae pollen. Single pollen grains of Pinus, Larix, and Picea are also characteristic for this zone. PZ-V can be subdivided into 2 subzones, the upper one $(50-0 \mathrm{~cm})$ showing the higher contents of Salix pollen.

P1 has also been studied for rhizopods (Table 2). The only sphagnobiotic/hygrophilic Heleopera petricola v. amethystea, pointing to a very wet environment, has been found at $463-473 \mathrm{~cm}$ depth. Mostly soil-eurybiotic (e.g. Centropyxis aerophila, $C$. constricta, $C$. sylvatica) and hydrophilic (Difflugia and Lagenodifflugia) species dominated the sediments between 334 and $223 \mathrm{~cm}$. However, sphagnobiotic taxa (Arcella, Heleopera, Nebela, Centropyxis aculeata) are also common. The role of soil-eurybiotic species gradually increases in the upper part.

\subsection{P2 core}

The core was retrieved $12.5 \mathrm{~km}$ away from $\mathrm{P} 1$ across the lake to the north $\left(67^{\circ} 32^{\prime} 50^{\prime \prime} \mathrm{N}, 172^{\circ} 07^{\prime} 31^{\prime \prime} \mathrm{E}\right)$, Fig. 1). The site is placed on a gently inclined $\left(<3^{\circ}\right)$ surface about $100 \mathrm{~m}$ from the north lake shoreline (for details see Schwamborn et al., 2008b). The surface is characterized by a boggy environment composed of a loamy substrate covered by grass tundra. Similar to core P1 deposits, core P2 is composed of 


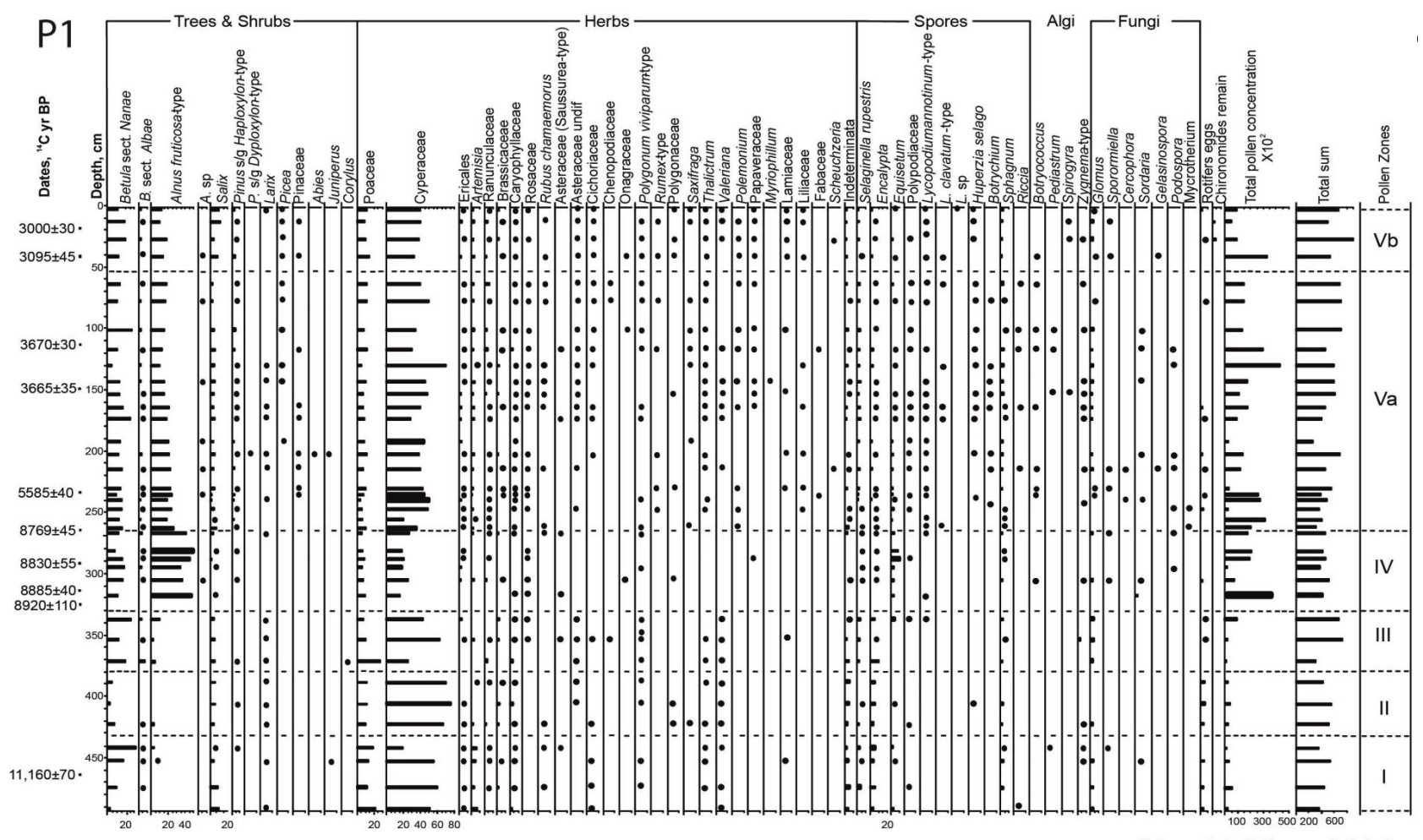

Fig. 3. Percentage pollen diagram of core P1. Dots are $<2 \%$ pollen contents.

a silty-to-sandy diamicton deposition (Schwamborn et al., $2008 \mathrm{~b})$. The lower part of the core $(510-250 \mathrm{~cm})$ is interpreted as weathering debris of the local volcanic basement. The upper $250 \mathrm{~cm}$ consists of proluvial slope washout deposits. The lithological transition between the units is also very distinguishable by an increase of TOC contents (Fig. 2).

Non-identified plant remains found in the $\mathrm{P} 2$ deposits have also been dated and show a rather reliable depth-age relationship (Table 1, Fig. 2). Three radiocarbon dates from the sediments between 205 and $226 \mathrm{~cm}$ depth demonstrates that these sediments might have accumulated about 14000 $12400 \mathrm{cal}$ yr BP. Taking into consideration the comparison with other dated pollen records from the area (Lozhkin et al., 2007; Matrosova, 2009; Glushkova et al., 2009), the youngest date seems to be the most reliable.

P2 core sediments are rich in pollen and palynomorphs except for the lowermost $170 \mathrm{~cm}$. The studied pollen spectra can be subdivided into $6 \mathrm{PZ}$ (Fig. 4). Sediments from PZ-I (ca. $510-350 \mathrm{~cm}$ ) contain only single pollen grains of Pinaceae, Betula sect. Nanae, Alnus fruticosa, and Cyperaceae. Pollen concentration is slightly higher in the lowermost sample which contains few pollen of Betula sect. Nanae, Alnus fruticosa, Pinus s/g Haploxylon and Cyperaceae. Pollen concentration is higher (up to 2650 grains/g) in PZ-II (ca. $350-330 \mathrm{~cm}$ ), which is also notable for high content of Lycopodium and Botrychium spores. The lowermost PZ-I and PZ-II were not used for paleoenvironmental reconstructions because of very low pollen concentration in many samples, which may lead to over-representing some taxa due to possible contamination or selective preservation of palynomorphs (e.g. abnormal presence of spores may indirectly point to it). Pollen concentration is much higher (up to 5800 grains/g) in PZ-III (ca. 330-265 cm), which is characterized by high pollen contents of Betula sect. Nanae, Alnus fruticosa, Cyperaceae, and Poaceae. Rather high amounts of Pinus s/g Haploxylon and Pinaceae are also notable in this zone. The pollen concentration increases significantly (up to 35700 grains/g) in PZ-IV (ca. 265-180 cm). Betula sect. Nanae and Alnus fruticosa pollen contents decreased dramatically at the beginning of the zone and gradually increased in the upper part. The zone can be subdivided in two subzones based on the shrub pollen contents. Pollen concentration is highest (up to 83600 grains $/ \mathrm{g}$ ) in PZ-V (ca. $180-40 \mathrm{~cm}$ ), which is dominated by pollen of Betula sect. Nanae, Alnus fruticosa, Salix, Cyperaceae, and Poaceae. Additionally, on the $146.5-151 \mathrm{~cm}$ depth seeds and short spurs of Larix dahurica as well as numerous utricle and nutlets of Carex rostrata were found. The uppermost PZ-VI (ca. $40-0 \mathrm{~cm}$ ) is characterized by decreasing Betula sect. Nanae and Alnus fruticosa pollen contents, while Cyperaceae, Pinus s/g Haploxylon and Salix pollen contents increased.

The P2 core has been also studied for rhizopods, but no tests were found there. 
Table 1. Radiocarbon and calibrated ages enclose the two-sigma range of highest probability. The ages have been calibrated using CALIB Rev 6.1.0. (Reimer et al., 2009). The obviously inversed ages were rejected dates and marked with *.

\begin{tabular}{|c|c|c|c|c|c|}
\hline $\begin{array}{l}\text { Depth }(\mathrm{cm}) \text {, } \\
\text { core }\end{array}$ & $\begin{array}{l}\text { Dated } \\
\text { material }\end{array}$ & $\begin{array}{l}{ }^{14} \mathrm{C} \text { ages } \\
(\mathrm{yr} \mathrm{BP})\end{array}$ & $\begin{array}{l}\text { Calibrated age } \\
\text { intervals (cal } \\
\text { yr BP) }\end{array}$ & $\begin{array}{l}\text { Lab. } \\
\text { number }\end{array}$ & Reference \\
\hline $20, \mathrm{P} 1$ & plant remains & $3000 \pm 30$ & $3078-3268$ & KIA25979 & Schwamborn et al. (2006) \\
\hline $43, \mathrm{P} 1$ & plant remains & $3095 \pm 45$ & $3209-3403$ & KIA25980 & Schwamborn et al. (2006) \\
\hline $114, \mathrm{P} 1$ & plant remains & $3670 \pm 30$ & $3906-4087$ & KIA23976 & Schwamborn et al. (2006) \\
\hline $150, \mathrm{P} 1$ & plant remains & $3665 \pm 35$ & $3890-4090$ & KIA25981 & Schwamborn et al. (2006) \\
\hline 207, P1 & plant remains & $8145 \pm 45^{*}$ & & KIA28241 & Schwamborn et al. (2006) \\
\hline $233, \mathrm{P} 1$ & plant remains & $5585 \pm 40$ & $4493-6447$ & KIA23977 & Schwamborn et al. (2006) \\
\hline $265, \mathrm{P} 1$ & plant remains & $8760 \pm 45$ & 9558-9914 & KIA23978 & Schwamborn et al. (2006) \\
\hline 292, P1 & plant remains & $8830 \pm 55$ & 9695-10 159 & KIA23979 & Schwamborn et al. (2006) \\
\hline $314, \mathrm{P} 1$ & plant remains & $8885 \pm 40$ & 9887-10 182 & KIA24865 & Schwamborn et al. (2006) \\
\hline $325, \mathrm{P} 1$ & plant remains & $8920 \pm 110$ & $9660-10249$ & KIA28242 & Schwamborn et al. (2006) \\
\hline $463, \mathrm{P} 1$ & plant remains & $11160 \pm 70$ & $12801-13243$ & KIA23980 & Schwamborn et al. (2006) \\
\hline $46, \mathrm{P} 2$ & grass remains & $1675 \pm 25$ & $1526-1626$ & KIA24866 & Schwamborn et al. (2008b) \\
\hline $52, \mathrm{P} 2$ & grass remains & $3365 \pm 35$ & $3553-3692$ & KIA27258 & Schwamborn et al. (2008b) \\
\hline $95, \mathrm{P} 2$ & grass remains & $4400 \pm 110$ & $4812-5320$ & KIA27259 & Schwamborn et al. (2008b) \\
\hline $119, \mathrm{P} 2$ & grass remains & $5350 \pm 45$ & $5998-6218$ & KIA27260 & Schwamborn et al. (2008b) \\
\hline $132 \mathrm{P} 2$ & grass remains & $6345 \pm 35$ & $7171-7330$ & KIA24867 & Schwamborn et al. (2008b) \\
\hline 146-151, P2 & Larix seeds & $9640 \pm 60$ & $10775-11193$ & Poz-42874 & this study \\
\hline $170-184, \mathrm{P} 2$ & bulk organic & $1890 \pm 100^{*}$ & & Poz-42875 & this study \\
\hline $205, \mathrm{P} 2$ & grass remains & $10450 \pm 60$ & $12116-12560$ & KIA24868 & Schwamborn et al. (2008b) \\
\hline $210, \mathrm{P} 2$ & grass remains & $11180 \pm 147$ & $12706-13320$ & KIA28243 & Schwamborn et al. (2008b) \\
\hline $226, \mathrm{P} 2$ & grass remains & $11790 \pm 242$ & $13113-14220$ & KIA28244 & Schwamborn et al. (2008b) \\
\hline $0-40,5011-3$ & plant remains & modern & & Poz-33404 & this study \\
\hline $40-50,5011-3$ & plant remains & modern & & Poz-33406 & this study \\
\hline $50-60,5011-3$ & plant remains & modern & & Poz-33407 & this study \\
\hline $60-70,5011-3$ & plant remains & modern & & Poz-33408 & this study \\
\hline $70-100,5011-3$ & plant remains & modern & & Poz-33409 & this study \\
\hline $100-110,5011-3$ & plant remains & modern & & Poz-33410 & this study \\
\hline $173-183,5011-3$ & bulk organic & $27690 \pm 200^{*}$ & & Poz-35975 & this study \\
\hline $208-230,5011-3$ & bulk organic & $20860 \pm 170^{*}$ & & Poz-35977 & this study \\
\hline $315-325,5011-3$ & bulk organic & $18800 \pm 120^{*}$ & & Poz-35978 & this study \\
\hline $395-400,5011-3$ & bulk organic & $24070 \pm 320^{*}$ & & Poz-35979 & this study \\
\hline $845-852,5011-3$ & bulk organic & $24590 \pm 220^{*}$ & & Poz-35980 & this study \\
\hline 899-910, 5011-3 & bulk organic & $28440 \pm 320^{*}$ & & Poz-35981 & this study \\
\hline
\end{tabular}

\section{$4.3 \quad 5011-3$ core}

The core was drilled on the western margin of the crater $\left(67^{\circ} 29^{\prime} 04^{\prime \prime} \mathrm{N}, 171^{\circ} 56^{\prime} 40^{\prime \prime} \mathrm{E}\right)$ approximately $300 \mathrm{~m}$ west from the lake shore (Fig. 1). This $141.5 \mathrm{~m}$ long core was recovered during a drilling campaign in winter 2008 within the framework of the international ICDP funded project "El'gygytgyn Drilling Project" (Melles et al., 2011). The main objective of the coring was to extend the permafrost record back in time in order to better understand the interaction between catchment processes and lake sedimentation. The sediment core drilled in an alluvial fan consists of sediment layers of sandy gravel to gravelly sand, which is interpreted to represent alternating subaerial and subaquatic parts of the fan. Occasionally intercalations of sandy beds occur, e.g. at $7,9,14.5,18-19.5,24$, and $26 \mathrm{~m}$. The modern setting of the coring site is placed in an alluvial-proluvial sediment fan, and from aerial imagery it is obvious that the fan has a subaquatic prolongation into the lake. In total, 12 samples from the core were AMS ${ }^{14} \mathrm{C}$ dated (Table 1). Although the non-identifiable plant remains (possibly grass roots) were picked throughout the upper meter of the core and expected to provide reliable age control for studied sediments, the ages appeared to be modern, reflecting the presence of modern plant roots in the active layer. The bulk AMS ${ }^{14} \mathrm{C}$ dates from some selected horizons (Table 1) did not provide reliable ages either. These ages are not in a chronological order, reflecting the reworked character of TOC in the samples. The ages are obviously too old, taking into consideration the comparison with other dated pollen records from the area (e.g. Matrosova, 2009; Glushkova et al., 2009; P1 and P2 records). Therefore, age estimations for the 5011-3 core are 


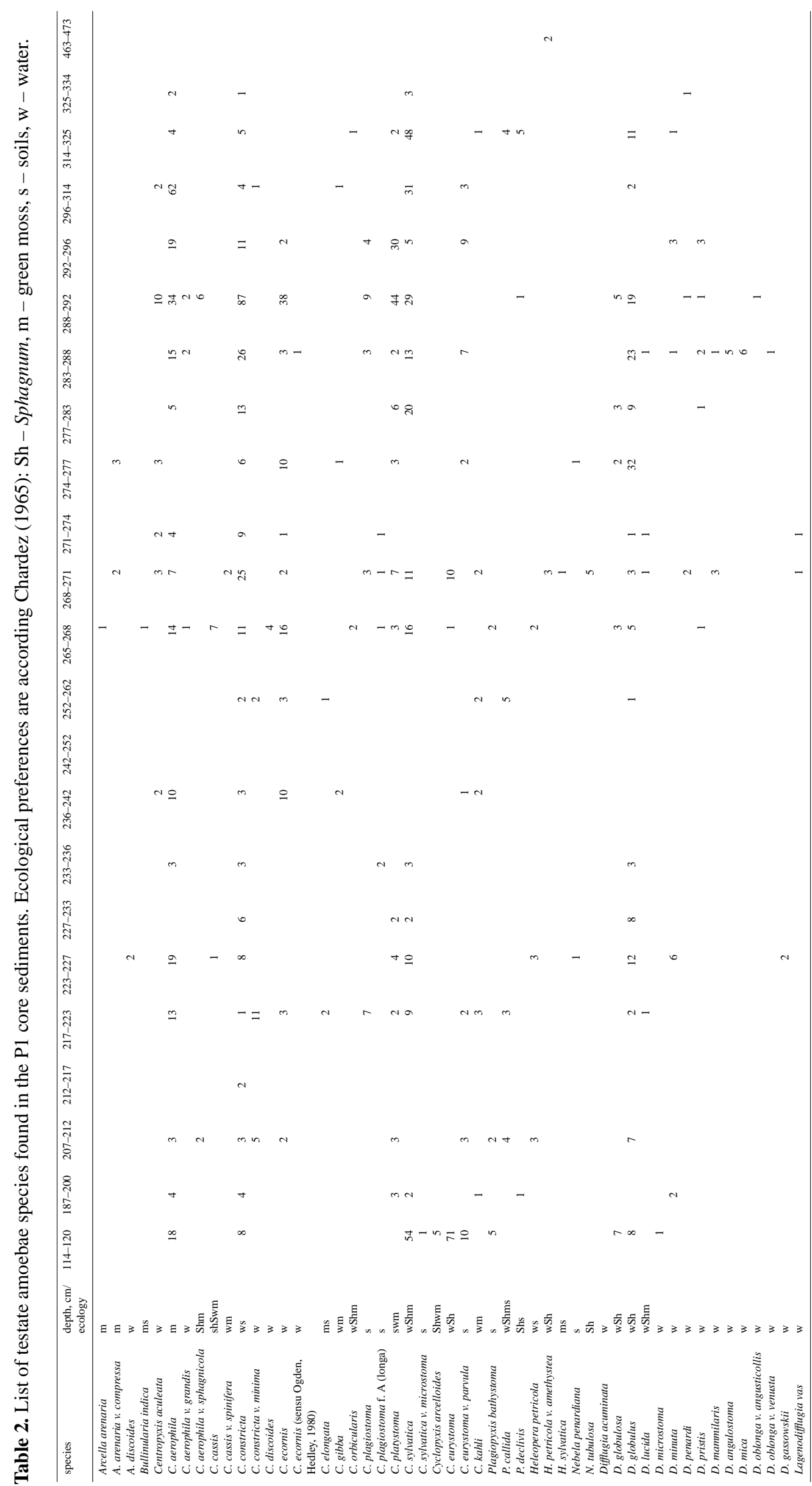


based on a comparison with the dated pollen sequences from the area.

Generally, the upper $9 \mathrm{~m}$ of 5011-3 sediments are rich in pollen and palynomorphs, but only single pollen grains were found below this depth, except in sediments between 19.8 and $19.3 \mathrm{~m}$ (Fig. 5). The studied pollen spectra can be subdivided into 7 PZ. PZ-I (ca. 1980-1930 cm) is dominated by Betula sect. Nanae, Alnus fruticosa, Salix, Cyperaceae, Poaceae, and Ericales pollen. The presence of Larix pollen and high contents of Sphagnum and Lycopodium spores is also characteristic for the zone, where pollen concentration is rather low (up to 3500 grains $/ g$ ). No pollen has been found between ca. 1930 and $1400 \mathrm{~cm}$ and only few pollen grains of Betula sect. Nanae, Alnus fruticosa, Salix, Cyperaceae, Poaceae and single spores of Sphagnum and Lycopodium have been found in PZ-II (ca. 1400-900 cm). PZ-III (ca. 900$330 \mathrm{~cm}$ ) is notable for much higher pollen concentration (up to 101330 grains/gr). The spectra are dominated by Betula sect. Nanae, Alnus fruticosa, Salix, Cyperaceae, Poaceae, Ericales and spores of Sphagnum. Contents of Sphagnum as well as pollen concentration reduced significantly in the upper PZ-IV (ca. $330-250 \mathrm{~cm}$ ). PZ-V (ca. $250-180 \mathrm{~cm}$ ) is notable for the significant increase of Poaceae pollen content, while contents of Betula sect. Nanae, Alnus fruticosa, Salix, Ericales and Sphagnum are dramatically decreased. The pollen concentration is the highest in the zone (up to 829400 grains/g). The contents of Betula and Alnus pollen increased again in PZ-VI (ca. $180-100 \mathrm{~cm}$ ), which is also notable for high content of Artemisia. The pollen concentration significantly (up to 15000 grains/g) reduced in this zone. The uppermost PZ-VII $(100-0 \mathrm{~cm})$ is dominated by Betula sect. Nanae, Alnus fruticosa, Cyperaceae, Poaceae, and Ericales, where pollen concentration is very high (up to 770000 grains/g). Single pollen of long-distance transported Pinus and Picea are also characteristic for this zone.

The 5011-3 core was also studied for rhizopods, but no tests were found.

\section{Discussion: paleoenvironmental reconstructions}

\subsection{MIS 7(?) environment}

The oldest pollen spectra are presented in the lower part $(1980$ to $1930 \mathrm{~cm})$ of the studied section of the core 5011 3 (PZ-I, Fig. 5). The pollen assemblages are dominated by Alnus fruticosa, Betula sect. Nanae and Poaceae. However, pollen of Larix, Salix, Cyperaceae, Ericales, Caryophyllaceae and spores of Sphagnum, Lycopodium and Huperzia are also important components of the revealed spectra. They are not dated but the comparison with lacustrine pollen records shows that spectra of our PZ-I are similar to those from the zone E14 of the TL-dated lacustrine core LZ1024 (Matrosova, 2009) and to those from the zone EG2 of the core PG1357 (Lozhkin et al., 2007). Based on the comparison of our record with the lacustrine records, we may suggest a MIS 7 (marine isotope stage 7) age for our PZ-I zone. However, an older age for the revealed interglacial interval cannot be completely excluded.

According to the pollen spectra, shrub alder, dwarf birch, and willows grew in the lake catchment. Relatively high content of larch pollen in the spectra (up to $4.5 \%$ ) requires the movement of northern boundary of larch forest at least $100 \mathrm{~km}$ to the north. Our conclusion is also supported by the lacustrine pollen records (Lozhkin et al., 2007; Matrosova, 2009). However, the cores drilled in the center of the El'gygytgyn Lake do not contain larch pollen at all and show low presence of Salix, Ericales, Caryophyllaceae pollen and Sphagnum, Lycopodium and Huperzia spores. This difference most likely reflects the larger presence of the local components in the 5011-3 core, pointing to the importance of studying of the terrestrial (non-lacustrine) sediments in addition to the lacustrine ones. Taking into consideration all El'gygytgyn pollen records, we assume that open larch forest with shrub alder, dwarf birch and willows dominated the local vegetation during the revealed warm interval. However, grass-sedge dominated communities with other herbs and Sphagnum and Lycopodium growing in mesic habitats were also common in lake vicinity.

\subsection{Lateglacial}

Lateglacial sediments are revealed in both radiocarbon dated slope cores (P1 and P2) and in the long permafrost 50113 core. Unfortunately, we do not have a good age control for the lowermost part of the core P1. Taking into consideration the P1 bottom age of $11160 \pm 70{ }^{14} \mathrm{C}$ yr BP (12 283-13424 cal yr BP), the most reliable P2 age of $10450 \pm 60{ }^{14} \mathrm{C}$ yr BP (12 124-12 654 cal yr BP), and pollenbased correlation with lacustrine pollen records (zone E4 of LZ1024 in Matrosova, 2009) we may assume that our PZ-I of P1 (Fig. 3), PZ-III of P2 (Fig. 4) and PZ-III and PZ-IV of 5011-3 (Fig. 5) accumulated during the Allerød, before 13 cal kyr.

Sediments attributed to the Allerød are dominated by pollen of Betula sect. Nanae, Alnus fruticosa, Salix, Cyperaceae, Poaceae, Ericales and spores of Sphagnum. The relatively high pollen concentration is also characteristic for the sediments. However, a number of samples show very low pollen concentrations or do not contain pollen at all. Most likely, this reflects a very high accumulation rate during the sedimentation. This conclusion is in a good agreement with thicknesses of Allerød-attributed deposits of about $2.5 \mathrm{~m}$ in the P2 core, and at least $6.5 \mathrm{~m}$ in the 5011-3 core. Warmer and wetter climate conditions in the Allerød may have intensified erosion and, therefore, produced higher influx of terrestrial material. The absence or very low thickness of the underlying Late Pleistocene sediments might also be connected with these erosion processes. 


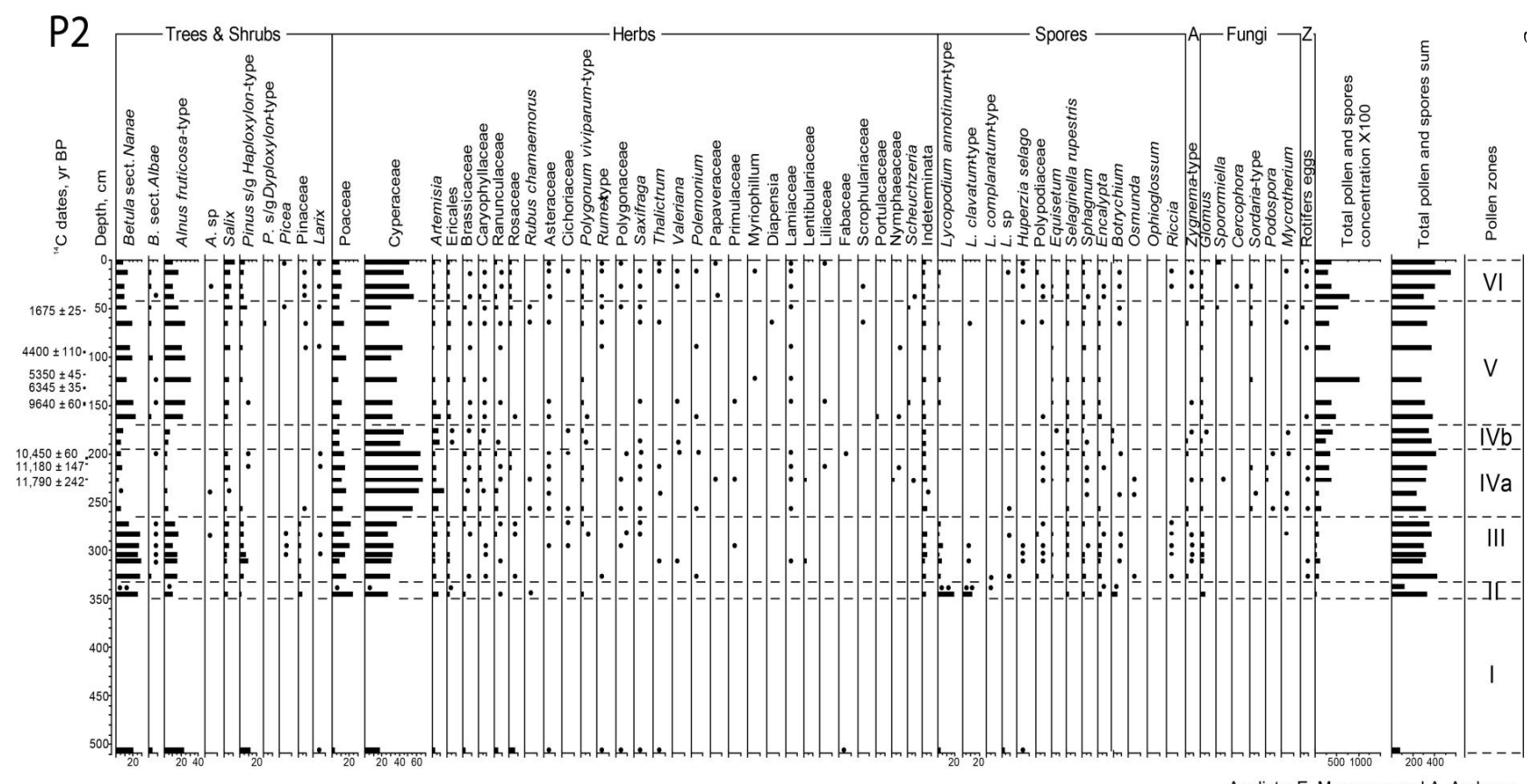

Fig. 4. Percentage pollen diagram of core P2. Dots are $<2 \%$ pollen contents.

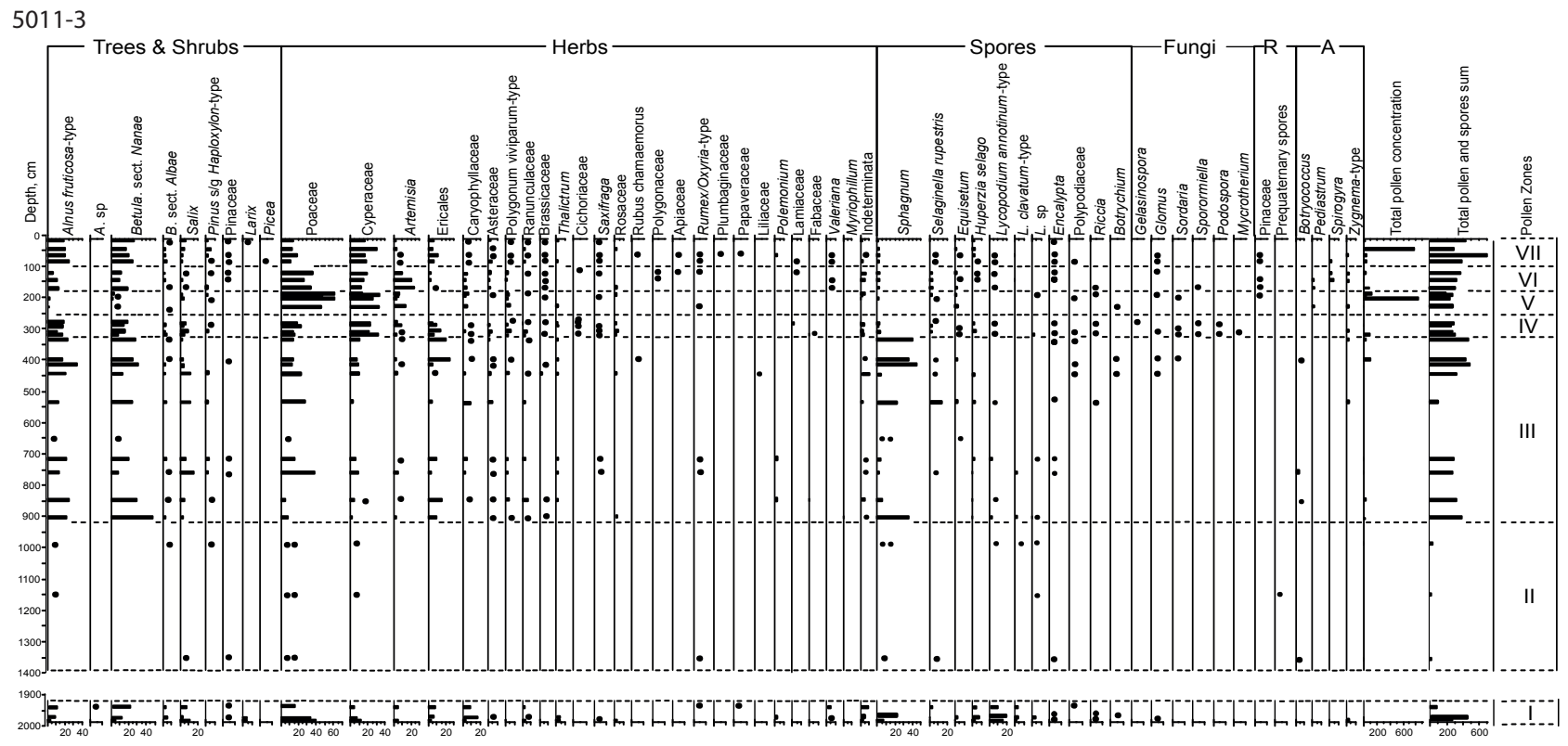

Analyists: A. Andreev \& E. Morozova

Fig. 5. Percentage pollen diagram of core 5011-3. Dots are $<2 \%$ pollen contents.

The main pollen taxa in the spectra slightly differ from site to site. For example, 5011-3 sediments contain large amounts of Salix and Ericales pollen and Sphagnum spores; P1 and P2 sediments contain numerous pollen of Cyperaceae; lacustrine pollen records contain larger amounts of long-distance pollen (including Betula and Alnus). However, the PG1351 lacustrine record also contains large amounts of Sphagnum spores in the late glacial sediments confirming wet habitats in the lake vicinity (Lozhkin et al., 2007). The sphagnobiotic rhizopod, Heleopera petricola, found in the Allerød-dated P1 sediments is in good agreement with numerous Sphagnum spores in the pollen records. Such habitats were probably common along the creeks as today. 
Our interpretation of the studied sediments is very similar to those from the PG1351 lacustrine record (Lozhkin et al., 2007; Matrosova, 2009) and from LZ1024 (Glushkova et al., 2009; Matrosova, 2009). Glushkova et al. (2009) also have reported pollen spectra with dominance of shrub pollen taxa from the undated terrace sediments (sections GS-10 and GS-12/1 in Fig. 1) attributed to a Late Glacial warm interval. Similar paleoenvironmental records are also known from adjacent regions (e.g. Brubaker et al., 2005; Lozhkin and Anderson, 2006; Shilo et al., 2006, 2007; Kokorowski et al., 2008; Andreev et al., 2009 and references therein). Lozhkin et al. (2007), based on their PG1351 lacustrine pollen record, have suggested that birch was regionally present at about $12800 \mathrm{yr}^{14} \mathrm{CBP}$ (15300 cal yr BP), while alder established in the area around $10700 \mathrm{yr}^{14} \mathrm{C} \mathrm{BP}(12700 \mathrm{cal} \mathrm{yr} \mathrm{BP})$.

There are plant macrofossil data from the sediments of section GS-37 (Fig. 1) ${ }^{14} \mathrm{C}$ dated to $12215 \pm 40 \mathrm{yr} \mathrm{BP}$ (14 027-14 491 cal yr BP). The studied sediments do not contain any shrub remains. Glushkova et al. (2009) interpreted this as the absolute absence of any shrub stands in the lake vicinity and very severe climate conditions. Thus, it seems that Allerød pollen and plant macrofossil data are contradictory. However, the conclusion about herb dominated tundra vegetation around $14250 \mathrm{cal}$ yr BP is based on the single studied sample, which reflects very wet, but not a typical tundra habitat. Moreover, they interpret the sediments containing numerous pebbles and eggs of Daphnia as the lake terrace periodically overflowed by the lake (Glushkova et al., 2009). It is obvious that shrubs cannot survive in such flooded habitats. Therefore, the found plant macrofossils reflect a very local, flooded habitat, which cannot be extrapolated to the whole lake vicinity.

Thus, according to the pollen spectra, shrub alder, dwarf birch and willows grew in the lake surrounding during the Allerød interstadial with relatively warm and wet climate (Melles et al., 2012). We can reconstruct shrub tundra vegetation with dwarf birch, shrub alder and willow around the lake.

Pollen spectra from PZ-II of P1 (Fig. 3), PZ-IVa of the core P2 (Fig. 4), and PZ-V of 5011-3 (Fig. 5) are dominated mostly by Cyperaceae and Poaceae pollen and reflect disappearance of shrubs from the area, pointing to drier and colder climate which can be attributed to the Younger Dryas. The most reliable ${ }^{14} \mathrm{C}$ dates from core $\mathrm{P} 2$ and P1 (Table 1) confirm this conclusion. Pollen spectra with a significant increase in herbs (mostly Poaceae) and Selaginella rupestris have also been revealed in the lacustrine sediments (E3 of LZ1024 in Matrosova, 2009), and are interpreted as reflecting the Younger Dryas event (Glushkova et al., 2009; Matrosova; 2009; Melles et al., 2012). Thus, grassherb tundra dominated the area during the Young Dryas cooling. Younger Dryas-dated pollen records from the adjacent regions (e.g. Anderson et al., 2002; Kokorowski et al., 2008; Andreev et al., 2009, 2011 and references therein) reflect similar environmental changes.

\subsection{Holocene}

Pollen spectra of the PZ-IVb of P2 (Fig. 4) accumulated before $9640 \pm 60{ }^{14} \mathrm{C}$ yr BP $(11200-10780 \mathrm{cal} \mathrm{yr} \mathrm{BP})$ show a gradual increase of Alnus fruticosa and Betula sect. Nanae pollen contents reflecting early Holocene climate amelioration. The early Holocene pollen assemblages are also well represented in the undated PZ-III of P1 (Fig. 3), where they are dominated mostly by pollen of Betula sect. Nanae, Cyperaceae and Poaceae with few Alnus fruticosa and Salix. Four ${ }^{14} \mathrm{C}$ dates (Table 1) confirm that these sediments were accumulated before $9000{ }^{14} \mathrm{C}$ yr BP $(10200 \mathrm{cal} \mathrm{yr} \mathrm{BP})$. Similar pollen assemblages have been revealed in the lowermost pollen zone of the so-called Olga Creek section (OC on Fig. 1, Shilo et al., 2008; Glushkova et al., 2009), situated ca. $100 \mathrm{~m}$ from P1 coring site. These lowermost spectra are also not ${ }^{14} \mathrm{C}$ dated, however two ${ }^{14} \mathrm{C}$ dates: $9250 \pm 90$ and $9125 \pm 30 \mathrm{yr} \mathrm{BP}$ from overlain sediments confirm that these sediments were accumulated before $9300{ }^{14} \mathrm{C}$ yr BP $(10550 \mathrm{cal}$ yr BP). Similar undated early Holocene pollen assemblages are also reported by Glushkova et al. (2009) from the section GS-12/1 (Fig. 1). Thus, we may assume that the earliest shrub tundra, with dwarf birches and willows and probably a few shrub alder, dominated the lake vicinity at the onset of the Holocene. The early Holocene pollen records from adjacent regions (e.g. Anderson et al., 2002; Anderson and Lozhkin, 2002; Kokorowski et al., 2008; Andreev et al., 2009 and references therein) have revealed similar environmental changes.

The contents of Alnus fruticosa are significantly higher in the PZ-V of the core $\mathrm{P} 2$ (up to $30 \%$ ) ${ }^{14} \mathrm{C}$ dated to ca. 9600 yr BP (11 200-10 780 cal yr BP) and PZ-IV of the core P1 (up to $50 \%$ ) ${ }^{14} \mathrm{C}$ dated around $8900-8800 \mathrm{yr} \mathrm{BP}$ (9940-9700 cal yr BP). Most likely, this increase reflects the further distribution of shrub alder stands in the area during the early Holocene. Pollen spectra of the PZ-V of P2 (Fig. 4) radiocarbon dated to about 7200-7300 cal yr BP, PZ-VI of 5011-3 (Fig. 5) and bottom spectra from the terrace section GS-8403 (Glushkova et al., 2009) and the section OC in the Enmyvaam River valley (Glushkova and Smirnov, 2007; Shilo et al., 2008; Glushkova et al., 2009) also demonstrate high amounts of Alnus fruticosa pollen in the early Holocene sediments. Moreover, the lacustrine sediments (Matrosova, 2009; Melles et al., 2012) accumulated above sediments attributed to the Younger Dryas also contain very high amounts of Alnus (up to $60 \%$ ). Large shrub alder trunks and smaller twig fragments ${ }^{14} \mathrm{C}$ dated to $9250 \pm 90$ and $9125 \pm 30 \mathrm{yr} \mathrm{BP}$ respectively, as well as numerous undated alder nuts from the same layers, well confirm that shrub alder grew in the lake vicinity at least $10550 \mathrm{cal}$ yr BP (Shilo et al., 2008). Thus, it is likely that shrub alder stands were well established in the El'gygytgyn Lake Crater at about 11200 cal yr BP or even slightly earlier.

The well-preserved larch seeds (Fig. 6) found in peaty layer in the core $\mathrm{P} 2$ prove the local presence of trees 


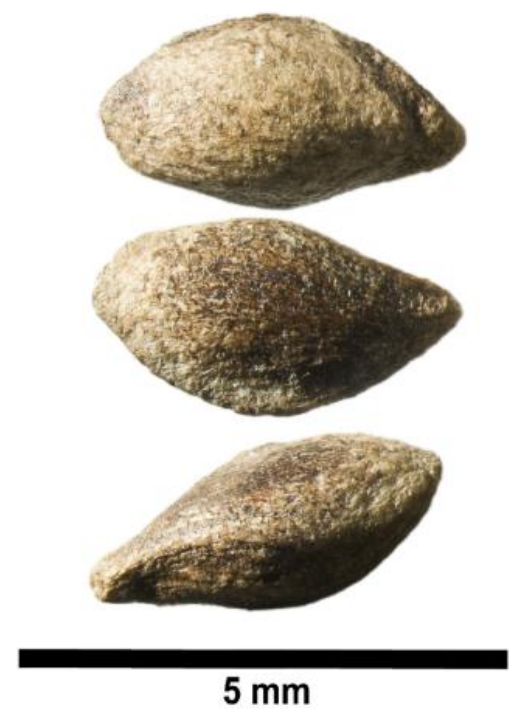

Fig. 6. Seeds of Larix found in core P2.

directly at the lake crater as early as $11200-10780$ cal yr BP. Larch remains were also found in the sediments accumulated shortly before $9300{ }^{14} \mathrm{C}$ yr BP (10 550 cal yr BP) from the OC section (Fig. 1, Shilo et al., 2008; Glushkova et al., 2009), thus, also confirming local presence of the larch trees at the area during the early Holocene. Such forest (tundraforest) environments are also good habitats for the shrub alder stands. The local presence of Larix indicates a treeline shift of about $100 \mathrm{~km}$ northward (CAVM-Team, 2003) as a result of the early Holocene climate amelioration. Larch requires a mean temperature of the warmest month of at least $10^{\circ} \mathrm{C}$, thus such climate conditions must have existed at the lake crater during the early Holocene.

The studied early Holocene pollen assemblages slightly differ from site to site. For example, the early Holocene 5011-3 spectra (PZ-VI) show high contents of Artemisia (up to $25 \%$ ), while GS-8403 spectra reported by Glushkova et al. (2009) contain up to $23 \%$ of Ericales. The difference may reflect the mosaic character of the local vegetation cover and/or different age of the revealed pollen assemblages. The lacustrine record (Matrosova, 2009; Melles et al., 2012) accumulated above the sediments attributed to the Younger Dryas shows very high amounts of Alnus (up to $60 \%$ ), which might have been transported from a distance and, thus, reflect the regionally dominated vegetation.

Rhizopod tests of soil-eurybiotic Centropyxis and hydrophilic Difflugia taxa (Table 2) are numerous in the P1 early Holocene sediments; however, sphagnobiotic Arcella, Heleopera, and Nebela are also common. The high contents of hydrophilic and sphagnophilic taxa point to wet oligotrophic and mesotrophic soil environment at the core site. Later, after ca. 6300 cal yr BP, the role of soil-eurybiotic species increased, reflecting drier soil environment.
Thus, pollen and macrofossil data show that forest and/or forest-tundra communities with larches, shrub alder, dwarf birches, and willows were well distributed at the low elevations around the lake during the early Holocene, at least between 11200 and 9100 cal yr BP. It is most likely that larch and shrub alder grew in the close vicinity to the lake only before ca. 8200 cal yr BP. Similar changes in the high Arctic vegetation cover are also characteristic for coastal areas of the Laptev and East Siberian Seas (e.g. Andreev et al., 2009, 2011 and references therein). Recovered larch remains document that larch grew approximately $100 \mathrm{~km}$ from its modern northern distribution limit. The mean July temperatures were at least $10-12{ }^{\circ} \mathrm{C}$ (Lozhkin and Anderson, 1995), ca. $4-5^{\circ} \mathrm{C}$ higher them modern July temperatures (Shilo et al., 2008). This is in agreement with the early Holocene pollen-based paleoclimate reconstruction from the El'gygytgyn lacustrine record (Lozhkin et al., 2007; Melles et al., 2012) and other high arctic sites (e.g. Andreev et al., 2009, 2011 and references therein).

A number of ${ }^{14} \mathrm{C}$ dates (Table 1) from P1 (PZ-Va) and P2 (PZ-V) cores confirm that permafrost sediments containing relatively high amounts of Alnus fruticosa pollen were accumulated until ca. $3500 \mathrm{cal}$ yr BP. Therefore, we may assume that shrub alder might grow around the lake in more protected habitats or very close to the lake vicinity before this time. This conclusion is in good agreement with pollen and plant macrofossil data from adjacent regions, documenting the presence of shrubs and trees to the north from modern distribution areas (e.g. MacDonald et al., 2000; Andreev et al., 2009, 2011; Binney et al., 2009 and references therein). However, the dated woody remains from the Enmyvaam River valley (Glushkova and Smirnov, 2007; Lozhkin et al., 2011) confirm the presence of high shrubs in the area only until ca. $7400{ }^{14} \mathrm{C}$ yr BP ( $8200 \mathrm{cal}$ yr BP). The studied deposits also contain the rather high amounts (up to $35 \%$ ) of Alnus fruticosa pollen in the sediments accumulated after $7400{ }^{14}$ C yr BP (Shilo et al., 2008; Lozhkin et al., 2011), pointing to a possible local presence of shrub alder; however, the age of the pollen assemblages is unknown.

Generally, late Holocene pollen spectra from the uppermost sediments (upper spectra of $\mathrm{PZ}-\mathrm{Vb}$ of the core $\mathrm{P} 1$, Fig. 3; PZ-VI of the core P2, Fig. 4; LZ-1024 record in Matrosova, 2009 and Melles et al., 2012) show a decrease in contents of Alnus fruticosa (mean values are up $20 \%$ and less) and some increases of contents of Salix, Pinus, Betula, Ericales, and Cyperaceae. These changes can be interpreted as disappearance of shrub alder from the lake vicinity. The main components of pollen assemblages slightly change from site to site, reflecting local vegetation cover at coring sites.

The late Holocene pollen assemblages are characterized by higher amounts of Pinus s/g Haploxylon. The modern boundary of the stone pine (Pinus pumila) is about $80 \mathrm{~km}$ from the study area (Vas'kovskiy, 1958); thus, it is most likely that all Pinus pollen grains are of long distance origin. 
Its pollen presence is especially remarkable in the uppermost lake sediments (Lozhkin et al., 2007; Matrosova, 2009) and the modern spectra (Matrosova, 2006), reflecting the extraregional vegetation pollen influx. Taking into consideration all pollen records from the study area, we may assume that stone pine did not grow around the lake during the Holocene.

Late Holocene sediments dated between ca. 900 and 450 cal yr BP (Glushkova et al., 2009) contain pollen spectra similar to those revealed in this study. They also show lower contents of Alnus pollen in many spectra and high fluctuations in Betula, Ericales, Thalictrum, and Selaginella rupestris, reflecting local environments. Thus, pollen data show that herb tundra communities started to dominate in the lake catchment after ca. 3000 cal yr BP.

\section{Conclusions}

New permafrost records document vegetation and climate changes in the El'gygytgyn Lake Crater during the Late Quaternary. The studied records reflect the local vegetation changes, resulting in a better understanding of the possible role of local and regional components in the fossil pollen spectra and in more reliable environmental reconstructions. It is evident that terrestrial records better reflect the local environments than the lacustrine ones where long-distance transported pollen overshadows the local components.

The oldest pollen spectra of the studied sections of the core 5011-3 are possibly of the MIS 7 age. They document that open larch forest with shrub alder, dwarf birch and willows dominate vegetation, suggesting the northern movement of larch forests. Treeless grass-sedge dominated communities with other herbs and Sphagnum and Lycopodium growing in mesic habitats were also common in the lake vicinity.

Lateglacial pollen records show that shrub tundra with dwarf birch, shrub alder and willow dominated in the lake surroundings during the relatively warm Allerød interstadial. Rather low pollen concentrations in many samples of Allerød age reflect very high accumulation rate during the sedimentation.

Younger Dryas pollen records reflect dramatic changes in the vegetation cover. Grass-sedge-herb tundra dominated the area, pointing to significantly drier and colder climate.

Forest-tundra with larches, dwarf birches and willows dominate the lake vicinity at the onset of the Holocene between ca. 11200 and 9100 cal yr BP. Shrub alder stands might grow at the low elevations around the lake during the Holocene, between ca. 11200 and 3500 cal yr BP. Later, similar-to-modern herb tundra communities dominated the El'gygytgyn Impact Crater.
Acknowledgements. Drilling operations for the ICDP 5011-3 core was funded by the International Continental Scientific Drilling Program (ICDP), the US National Science Foundation (NSF), the German Federal Ministry of Education and Research (BMBF), Alfred Wegener Institute (AWI) and Helmholtz Centre Potsdam (GFZ), the Russian Academy of Sciences Far East Branch (RAS FEB), the Russian Foundation for Basic Research (RFBR), and the Austrian Federal Ministry of Science and Research (BMWF). Funding of core analyses was provided by BMBF (grant no. 03G0642). We are grateful to M. Edwards, Bernd Wagner and an anonymous reviewer for their constructive comments and suggestions. Special thanks also go to Alison McAnena for reviewing the English.

Edited by: B. Wagner

\section{References}

Anderson, P. M. and Lozhkin, A. V. (Eds.): Palynological and radiocarbon data from Quaternary deposits of northeastern Siberia, in: Quaternary vegetation and climate of Siberia and Russian Far East: a palynological and radiocarbon database, NOAA Paleoclimatology and North-East Science Center, Magadan, 27-34, 2002.

Anderson, P. M., Lozhkin, A. V., and Brubaker, L. B.: Implications of a 24,000-yr palynological record for a Younger Dryas cooling and for boreal forest development in Northeastern Siberia, Quatern. Res., 57, 325-333, 2002.

Andreev, A. A., Grosse, G., Schirrmeister, L., Kuznetsova, T. V., Kuzmina, S. A., Bobrov, A. A., Tarasov, P. E., Novenko, E. Yu., Meyer, H., Derevyagin, A. Yu., Kienast, F., Bryantseva, A., and Kunitsky, V. V.: Weichselian and Holocene paleoenvironmental history of the Bol'shoy Lyakhovsky Island, New Siberian Archipelago, Arctic Siberia, Boreas, 38, 72-110, 2009.

Andreev, A., Schirrmeister, L., Tarasov, P., Ganopolski, A., Brovkin, V., Siegert, C., and Hubberten, H.-W.: Vegetation and climate history in the Laptev Sea region (arctic Siberia) during Late Quaternary inferred from pollen records, Quaternary Sci. Rev., 30, 2182-2199, 2011.

Belikovich, A. V.: Permanent monitoring in the El'gygytgyn Lake area, IBPS FEB RAS, Magadan, 1988.

Belikovich, A. V.: Graf method by analyses of habitats in a landscape unit using environment characteristics (El'gygytgyn Lake, central Chukotka as a model), in: Graf method in ecology, edited by: Galanin, A. V., FEB RAS, Vladivostok, 104-111, 1989.

Belikovich, A. V.: Recreation sources of planned "El'gygytgyn Lake Park", FEB RAS, Vestnik, 3, 57-63, 1994.

Belikovich, A. V. and Galanin, A. V.: "El'gygytgyn Lake" Reservation (central Chukotka), FEB RAS, Vestnik, 4, 22-24, 1994.

Belyi, F. V.: Impactogenesis and volcanism of El'gygytgyn depression, Petrology, 6, 86-99, 1998.

Berglund, B. E. and Ralska-Jasiewiczowa, M.: Pollen analysis and pollen diagrams, in: Handbook of Holocene palaeoecology and palaeohydrology, edited by: Berglund, B. E., Wiley, Chichester, 455-484, 1986.

Binney, H. A., Willis, K. J., Edwards, M. E., Bhagwat, S. A., Anderson, P., Andreev, A. A., Blaauw, M., Damblon, F., Haesaerts, P., Kienast, F. W., Kremenetski, K. V., Krivonogov, S. K., Lozhkin, A. V., MacDonald, G. M., Novenko, E. Y., Oksanen, P., Sapelko, 
T. V., Valiranta, M., and Vazhenina, L.: The distribution of lateQuaternary woody taxa in Eurasia: evidence from a new macrofossil database, Quaternary Sci. Rev., 28, 2445-2464, 2009.

Blunier, T. and Brook, E. J.: Timing of millennial-scale climate change in Antarctica and Greenland during the last glacial period, Science, 291, 109-112, 2001.

Bobrov, A. E., Kupriyanova, L. A., Litvintseva, M. V., and Tarasevich, V. F.: Spores and pollen of gymnosperms from the flora of the European part of the USSR, Nauka, Leningrad, 1983.

Brigham-Grette, J., Melles, M., Minyuk, P., and Scientific Party: Overview and significance of a 250-ka paleoclimate record from El'gygytgyn Crater Lake, NE Russia, J. Paleolim., 37, 1-16, 2007.

Brubaker, L. B., Anderson, P M., Edwards, M. E., and Lozhkin, A. V.: Beringia as a glacial refugium for boreal trees and shrubs: new perspectives from mapped pollen data, J. Biogeogr., 32, 833-848, 2005.

Chardez, D.: Ecologie generale des Thecamoebiens (Rhizopoda, Testacea), Bulletin de 1'Institut Agronomigue et des Stations de Recherches Gembloux, 2, 306-341, 1965.

CAVM-Team: Circumpolar Arctic Vegetation Map, Conservation of Arctic Flora and Fauna (CAFF) Map No. 1, US Fish and Wildlife Service, Anchorage, Alaska, 2003.

Egorova, T. V.: The sedges (Carex L.) of Russia and adjacent states, St. Petersburg State Chemical-Pharmaceutical Academy, St. Petersburg, 1999.

Galanin, A. V., Belikovich, A. V., Galanin, A. A., and Tregubov, O. D.: Priroda i resursy Chukotki (Nature and sources of Chukotka), IBPS FEB RAS, Magadan, 1997.

Glushkova, O. Y. and Smirnov, V. N.: Pliocene to Holocene geomorphic evolution and paleogeography of the El'gygytgyn Lake region, NE Russia, J. Paleolim., 37, 37-47, 2007.

Glushkova, O. Y., Smirnov, V. N., Matrosova, T. V., Vazhenina, L. N., and Braun, T. A.: Climatic-stratigraphic characteristic and radiocarbon dates of terrace complex in El'gygytgyn Lake basin, FEB RAS, Vestnik, 2, 31-43, 2009.

Grimm, E. C.: TGView, Illinois State Museum, Research and Collections Center, Springfield, 2004.

Gurov, E. P. and Gurova, E. P.: Stages of shock metamorphism of silica volcanic rocks in the El'gygytgyn meteorite Crater, Chukotka, Dokl. Akad. Nauk SSSR, 249, 121-123, 1979.

Johnsen, S. J., Dahl-Jensen, D., Dansgaard, W., and Gundestrup, N.: Greenland palaeotemperatures derived from GRIP borehole temperature and ice core isotope profiles, Tellus B, 47, 624-629, 1995.

Kokorowski, H. D., Anderson, P. M., Sletten, R. S., Lozhkin, A. V., and Brown, T. A.: Late Glacial and early Holocene climatic changes based on a multiproxy lacustrine sediment records from Northeast Siberia, Arct. Antarct. Alp. Res., 40, 497-505, 2008.

Kozhevnikov, Yu. P.: Vascular plants around El'gygytgyn Lake, in: Natural depression El'gygytgyn Lake (problems of study and preservation), NEISRI FEB RAS, Magadan, 62-82, 1993.

Kupriyanova, L. A. and Alyoshina, L. A.: Pollen and spores of plants from the flora of European part of USSR, Vol. I., Academy of Sciences USSR, Komarov Botanical Institute, Leningrad, 1972.

Kupriyanova, L. A. and Alyoshina, L. A.: Pollen and spores of plants from the flora of European part of USSR, Academy of Sciences USSR, Komarov Botanical Institute, Leningrad, 1978.
Layer, P.: Argon-40/argon-39 age of the Elgygytgyn impact event, Chukotka, Russia, Meteorol. Planet. Sci., 35, 591-599, 2000.

Lozhkin, A. V. and Anderson, P. M.: The Last Interglaciation in Northeast Siberia, Quatern. Res., 43, 147-158, 1995.

Lozhkin, A. V. and Anderson, P. M.: A reconstruction of the climate and vegetation of Northeastern Siberia based on lake sediments, Paleontol. J., 40, 622-628, 2006.

Lozhkin, A. V., Anderson, P. M., Matrosova, T. V., and Minyuk, P. S.: The pollen record from El'gygytgyn Lake: implications for vegetation and climate histories of northern Chukotka since the late middle Pleistocene, J. Paleolimnol., 37, 135-153, 2007.

Lozhkin, A. V., Anderson, P. M., and Vazhenina, L. N.: Younger Dryas and early Holocene peats from northern Far East Russia, Quatern. Int., 237, 54-64, 2011.

MacDonald, G. M., Velichko, A. A., Kremenetski, C. V., Borisova, O. K., Goleva, A. A., Andreev, A. A., Cwynar, L. C., Riding, R. T., Forman, S. L., Edwards, T. W. D., Aravena, R., Hammarlund, D., Szeicz, J. M., and Gataullin, V. N.: Holocene treeline history and climate change across Northern Eurasia, Quatern. Res., 53, 302-311, 2000.

Matrosova, T. V.: Modern spore-pollen spectra of Anadyr Plateau (El'gygytgyn Lake), in: Geology, geography and biodiversity of North-East Russia, Materials of Far-East regional conference in memory of A. P. Vas'kovskiy, edited by: Chereshnev, I. A., NEISRI FEB RAS, Magadan, 159-162, 2006.

Matrosova, T. V.: Vegetation and climate change in northern Chukotka during the last $350 \mathrm{ka}$ (basing on lacustrine pollen records from El'gygytgyn Lake, FEB RAS, Vestnik, 2, 23-30, 2009.

Matrosova, T. V., Anderson, P. M., Lozhkin, A. V., and Minyuk, P. S.: Climate history of Chukotka during the last 300,000 years from the Lake El'gygytgyn pollen record, in: Climate records from Quaternary sediments of Beringia, edited by: Lozhkin, A. V., NEISRI FEB RAS, Magadan, 26-42, 2004.

Melles, M., Brigham-Grette, J., Minyuk, P., Koeberl, C., Andreev, A., Cook, T., Fedorov, G., Gebhardt, C., Haltia-Hovi, E., Kukkonen, M., Nowaczyk, N., Schwamborn, G., Wennrich, V., and the El'gygytgyn Scientific Party: The Lake El'gygytgyn Scientific Drilling Project - Conquering Arctic Challenges in Continental Drilling, Sci. Drill., 11, 29-40, 2011.

Melles, M., Brigham-Grette, J., Minyuk, P. S., Nowaczyk, N. R., Wennrich, V., DeConto, R. M., Anderson, P. M., Andreev, A., Coletti, A., Cook, T., Haltia-Hovi, E., Kukkonen, M., Lozhkin, A. V., Rosén, P., Tarasov, P., Vogel, H., and Wagner, B.: 2.8 Million Years of Arctic Climate Change from Lake El'gygytgyn, NE Russia, Science, 337, 315-320, 2012.

Nolan, M. and Brigham-Grette, J.: Basic hydrology, limnology, and meteorology of modern El'gygytgyn Lake, Siberia, J. Paleolimnol., 37, 17-35, 2007.

Reille, M.: Pollen et spores d'Europe et d'Afrique du nord, Laboratoire de Botanique Historique et Palynologie, Marseille, 1992.

Reille, M.: Pollen et spores d'Europe et d'Afrique du nord, supplement 1, Laboratoire de Botanique Historique et Palynologie, Marseille, 1995.

Reille, M.: Pollen et spores d'Europe et d'Afrique du nord, supplement 2, Laboratoire de Botanique Historique et Palynologie, Marseille, 1998. 
Reimer, P. J., Baillie, M. G. L., Bard, E., Bayliss, A., Beck, J. W., Blackwell, P. G., Bronk Ramsey, C., Buck, C. E., Burr, G. S., Edwards, R. L., Friedrich, M., Grootes, P. M., Guilderson, T. P., Hajdas, I., Heaton, T. J., Hogg, A. G., Hughen, K. A., Kaiser, K. F., Kromer, B., McCormac, F. G., Manning, S. W., Reimer, R. W., Richards, D. A., Southon, J. R., Talamo, S., Turney, C. S. M., van der Plicht, J., and Weyhenmeyer, C. E.: IntCal09 and Marine09 Radiocarbon Age Calibration Curves, 0-50,000 Years cal BP, Radiocarbon, 51, 1111-1150, 2009.

Schwamborn, G., Meyer, H., Fedorov, G., Schirrmeister, L., and Hubberten, H.-W.: Ground ice and slope sediments archiving Late Quaternary paleoenvironment and paleoclimate signals at the margins of Elgygytgyn Impact Crater, NE Siberia, Quatern. Res., 66, 259-272, 2006.

Schwamborn, G., Förster, A., Diekmann, B., Schirrmeister, L., and Fedorov, G.: Mid to late Quaternary cryogenic weathering conditions in Chukotka, northeastern Russia: Inference from mineralogical and microtextural properties of the El'gygytgyn Crater Lake sediment record, in: Ninth International Conference on Permafrost, Institute of Northern Engineering, University of Alaska Fairbanks, 1601-1606, 2008a.

Schwamborn, G., Fedorov, G., Schirrmeister, L., Meyer, H., and Hubberten, H.-W.: Periglacial sediment variations controlled by late Quaternary climate and lake level change at El'gygytgyn Crater, Arctic Siberia, Boreas, 37, 55-65, 2008 b.

Shilo, N. A., Lozhkin, A. V., Anderson, P. M., Belaya, B. V., Stetsenko, T. V., Glushkova, O. Yu., Brigham-Grette, J., Melles, M., Minyuk, P. S., Nowaczyk, N., and Forman, S.: First continuous pollen record of vegetation and climate change in Beringia during the last 300 thousand years, Dokl. Akad. Nauk, 376, 231$234,2001$.
Shilo, N. A., Lozhkin, A. V., Anderson, P. M., Brown, T. A., Matrosova, T. V., and Kotov, A. T.: Radiocarbon dates and palynological characteristics of sediments in Lake Melkoe, Anadyr River Basin, Chukotka, Dokl. Akad. Nauk, 407, 235-237, 2006.

Shilo, N. A., Lozhkin, A. V., Anderson, P. M., Brown, T. A., Pakhomov, A. Yu., and Solomatkina, T. B.: Glacial refugium of Pinus pumila (Pall.) Regel in northeastern Siberia, Dokl. Akad. Nauk, 412, 401-403, 2007.

Shilo, N. A., Lozhkin, A. V., Anderson, P. M., Vazhenina, L. N., Stetsenko, T. V., Glushkova, O. Yu., and Matrosova, T. V.: First data on the expansion of Larix gmelinii (Rupr.) Rupr. into arctic regions of Beringia during the early Holocene, Dokl. Akad. Nauk, 423, 680-682, 2008.

Stockmarr, J.: Tablets with spores used in absolute pollen analysis, Pollen Spores, 13, 614-621, 1971.

Stuiver, M., Grootes, P. M., and Braziunas, T. F.: The GISP2 $\delta^{18} \mathrm{O}$ climate record of the past 16,500 years and the role of the sun, ocean, and volcanoes, Quatern. Res., 44, 341-354, 1995.

Van Geel, B.: Non-pollen palynomorphs, in: Tracking environmental change using lake sediments, in: Terrestrial, algal and silicaceous indicators, Vol. 3, edited by: Smol, J. P., Birks, H. J. B., Last, W. M., Bradley, R. S., and Alverson, K., Kluwer, Dordrecht, 99-119, 2001.

Vas'kovskiy, A. P.: New data about distribution limits of trees and shrubs in extreme North-East of USSR, Materialy po geologii i poleznym iskopaemym severo-vostoka SSSR, 13, Magadan Publishing House, 187-204, 1958. 